\title{
FOXP4 Gene
}

National Cancer Institute

\section{Source}

National Cancer Institute. FOXP4 Gene. NCI Thesaurus. Code C150232.

This gene plays a role in the tissue-specific repression of gene transcription. 